\title{
SOURCES OF AIR POLLUTION, ENVIRONMENTAL IMPACTS AND EXPLOITATION OF NATURAL RESOURCES IN KOSOVO
}

\author{
Adem Dreshaj, ${ }^{1}$ Bedri Millaku, ${ }^{2}$ Sabiha Shala, ${ }^{3}$ Afrim Selimaj, ${ }^{4}$ Halit Shabani ${ }^{5}$
}

\begin{abstract}
Concerns and uncertainty about the life on Earth are constantly growing, today greater than ever before, as a result of human activity. In this regard, the major dangers that threaten our planet include uncontrolled utilization of natural resources, environmental deterioration and environmental pollution over Earth's regenerating possibilities. Whereas, the main causes of pollution are deforestation, erosion, greenhouse gas emissions, poor urban and industrial waste control and uncontrolled mining activities. All of these lead to serious consequences for life on Earth, because of the natural resources of the soil and its capacity to absorb waste gases $\left(\mathrm{CH}_{4}\right)$, and the release of heavy metals such as $\mathrm{Pb}, \mathrm{Zn}, \mathrm{Cd}, \mathrm{Cu}, \mathrm{Fe}$ and $\mathrm{As}$, which are the biggest soil pollutants. The Earth is being cemented, and its regenerating capacities are being diminished every day.
\end{abstract}

UDC Classification: 502/504; DOI: http://dx.doi.org/10.12955/cbup.v5.1111

Keywords: Emission, pollution, tourism, sustainability

\section{Introduction}

As Shehu (2006) claims, the non-regenerating natural resources are the ones that when used cannot be replaced. This is the case with fuels and mineral exploitation. But in practice, it has been stated that even renewable resources, such as forests, waters, etc., when used irrationally might have consequences on the environment.

Certain human activities might lead to significant environmental damage, irreversible, to the disorder of natural balances (Law No. 03/1-233 on nature protection, 2013). Additionally, the rapid growth of the global population, followed by the desire for a higher standard of material living has led to the environmental damages on a global scale (Qullaj, 2010).

On the one hand, industrialized countries that comprise only $1 / 4$ of the world's population consume about $82 \%$ of natural resources. On the other hand, the capacities of Earth to keep people and other living things safe have been considerably diminished (Lajçi \& Kalaj, 1998). In less than 180 years, our planet has lost about 6.2 million $\mathrm{km}^{2}$ of forests, while the extraction of water has been increased from 100 to $3600 \mathrm{~km}^{3}$ per year (Daci, 1978).

Therefore, air and soil pollution and the shortage of drinking water and natural waters have become a serious and persistent threat to the health of human beings and the living world in general.

\section{Environmental pollution with heavy metals}

According to the UN report (2005), about $1 / 2$ of the global population of 6.3 billion people live in cities, and this number might increase to 5 billion or $61 \%$ of the population by 2030 (Law Nr. 04/ L147 on Water, 2013).

In addition, a dramatic rise in population marked a number of cities. Today, there are more than 22 cities with populations of over 11 million (Lajçi \& Kalaj, 1998). It is estimated that three-quarters of the population in developed countries live in cities. Our civilization is endangered today because people abuse natural resources and damage the natural systems of the Earth while pushing the limits of the earth's capacity (Shehu, 2006). This situation has concerned not only scientists and politicians but also citizens, wherever they are on the globe (Dreshaj, 2013).

In general, nowadays, atmospheric air pollution has become a great concern (Daci, 1978). The main causes are economic and industrial development, and also living conditions (Qullaj, 2010).

Also, the pollution of air has been affected by the undeveloped industry, the introduction of obsolete technologies, the growth of cities, the unplanned and illegal construction, the approach of residential

\footnotetext{
1 "Haxhi Zeka" University, Peja, Kosovo, adem.dreshaj@ unhz.eu

2 "Haxhi Zeka" University, Peja, Kosovo, bedri.millaku@unhz.eu

3 "Haxhi Zeka" University, Peja, Kosovo, sabiha.shala@unhz.eu

4 “Haxhi Zeka” University, Peja, Kosovo, afrim.selimaj@unhz.eu

5 “Haxhi Zeka” University, Peja, Kosovo, halit.shabani@unhz.eu
} 
areas near industrial sites, the reduction of green areas (parks and gardens), increased vehicle traffic, and use of high-content lead fuels (Dreshaj, 2013).

\section{Geographical position and the development of tourism in Kosovo}

According to Qullaj (2010), Kosovo is characterized by a suitable geographic position. It lies in the southeast Europe and in the central part of the Balkan Peninsula, thus being an important crossroad of transitional roads connecting various parts of Europe and beyond it since the ancient times to the present day.

The geographic position gained particular importance after the construction of the ThessalonikiSkopje-Kosovo Polje-Mitrovica railroad in 1874, which connected the southern and northern parts of the Balkans and Europe (Besa, 2015).

The transit function increased further with the construction of the Ferizaj - Prishtina - Mitrovica road which continued along the valley of Iber by creating links with central and western Europe, whereas, through Kacanik connected to the south and - Corridor 8, Durres-Skopje-Sofia-Varna (Besa, 2015). Construction of the Adriatic highway (1971) increased the transitory links of Kosovo with the Adriatic coast and widened the Dalmatian corridor turning Kosovo into an important regional crossroad (Shehu, 2006).

The Relief

The most important forms of relief are hollows (Kosovo, Dukagjin, etc.), and mountains (Sharri, Albanian Alps - Rugova Mountains, Kopaonik), etc. Mountains account for 64\%, while the hollows account for 36\% of Kosovo's territory (Law on waste, 2012). The average altitude of Kosovo is $810 \mathrm{~m}$ with the extremes between $270 \mathrm{~m}$, the lowest point in Vermica, and $2656 \mathrm{~m}$, the highest point in Gjeravica (Besa, 2015).

In terms of hypsometric aspect, areas under $700 \mathrm{~m}$ comprise more than half of the territory of Kosovo (52.6\%), 700-1000 $\mathrm{m}$ areas comprise more than a quarter $(26.6 \%)$, while surfaces over $1000 \mathrm{~m}$ account over 1/5 (20.8\%), of the territory of Kosovo (Law No. 03/L-160 on air protection from pollution, 2010). The relief represents a very important influential element of the climate, hydrograph, the establishment, and development of dwelling places or settlements, etc. (Qullaj, 2010).

The climate of Kosovo is under the influence of macro-climate factors: geographic latitude, land position, water, based on the macro - climate factors. Thus, Kosovo is characterized by a moderate continental climate, but local factors also affect the situation of other climate types (Shehu, 2006).

Depending on these factors, the eastern part (Kosovo Plain) is characterized by a continental climate, whereas, the western part (Dukagjin Plain) is characterized by an average continental climate with a significant influence of the Mediterranean climate of the Adriatic Sea through the Drini Valley.

Hilly mountainous areas (750-1000 m), as transitional areas are characterized by subalpine climate and mountainous areas (over $1000 \mathrm{~m}$ ), are characterized by alpine climate (Besa, 2015). Kosovo's average temperatures are around $11{ }^{\circ} \mathrm{C}$ with the minimum temperature $-25.2{ }^{\circ} \mathrm{C}$ and the maximum up to $39.2^{\circ} \mathrm{C}$. Maximum average annual rainfall is $591 \mathrm{~mm}$. Due to the impact of local factors, the western part of Kosovo is characterized by a higher temperature (average for $1{ }^{\circ} \mathrm{C}$ higher), and a higher average amount of precipitation (by around $100 \mathrm{~mm}$ ) than the eastern part of Kosovo.

\section{Air pollution}

The air is an important environmental factor and a necessity for life. Its pollution is caused by mixed substances that come in the natural or artificial ways and become the main reason of deterioration of its quality, causing a series of illnesses, and degradation of other environmental elements (Lajçi \& Kalaj, 1998).

Air pollution poses a great danger to the population, particularly to high-risk groups, such as children and the elderly (Shehu, 2006). Air quality deterioration is caused by the presence of pollutants such as $\mathrm{SO}_{2}, \mathrm{NOx}$, and particulate matter in abeyance (PMA), troposphere ozone, carbon monoxide, volatile organic compounds and heavy metals (Daci, 1978). Also, transport growth is accompanied by increased pollution from $\mathrm{NOx}, \mathrm{PM}, \mathrm{O}_{3}$, carbon monoxide, and hydrocarbons. 


\section{Cycles of air pollution}

Three cycles are considered as the most important regarding the air pollutants on the environment:

- The first cycle is the process of emission, that is characterized by parameters such as the type of pollutants, the quantity of pollutants, the scale of the source of discharge, the temperature of the material emitted, the speed and time of the emitted material;

- The second cycle is the atmospheric transport of pollutants. It includes possible physical or chemical factors, for example, photochemical reactions and the spatial distance between the source of the discharged pollutant and the area which the pollutant affects.

- The deposition process is the third cycle. The deposition means the local impact of pollutants on the environment. It depends on the weather conditions or climate change, such as the inversion of temperature or precipitation and their duration (Lajçi \& Kalaj, 1998).

\section{Air pollution modeling}

Modelling techniques are some of the most important instruments dealing with air quality. The models are useful for predicting the behavior of systems, which are too complex for accurate analysis of the subject. Likewise, models are used to predict the worst cases of pollution (Qullaj, 2010).

Factors in the spread of polluting particles are:

- Wind, which is dependent on the shape (roughness) of the surface of the Earth;

- The effect of friction between the air and the earth's surface, wind speed, and turbulence;

- Wind speed decreases significantly closer to ground level, if the surface is relatively rough, for example. With trees and buildings, airflow tends to turn into turbulence, and increasing wind speed with height from ground level is relatively small (Davis \& Mc Entire, 2006).

\section{Sources of air pollution in the Republic of Kosovo}

Resources of mining and energy in Kosovo are used in an uncontrolled manner, neglecting the condition of the environment, without adequate environmental projects and adequate professional treatment of the case. Hence, this situation is causing major damage to human health and the environment in general (air, water, soil and natural landscapes). In 1988/99, energy, non-ferrous metals and processing of metals comprised about $65 \%$ of the industrial production in Kosovo (Law No. 04/L-06 on waste, 2012).

According to reports, the concentration of lead in the air in 1980/91 was increased from 22.9 to 25.2 micrograms for $\mathrm{m}^{3}$. Except for $\mathrm{SO}_{2}, \mathrm{NOx}$, the organic substances that were emitted in the air in 1990 and further on, are as follows:

- Dust 4910 t/year;

- Lead 1120 t/year.

Great potential pollutants are found from other metals such as $\mathrm{Ag}, \mathrm{As}, \mathrm{Cd}, \mathrm{Cu}, \mathrm{Fe}, \mathrm{Pb}, \mathrm{Zn}$, etc.

Whereas, a particular problem derives from the following indicators:

- Slag of smelters in million tonnes;

- Wastes from electrolysis of approximately 560,000 tones Zn;

- Waste of frying concentrates nearly 760000 tonnes;

- Trash flotation;

- Old landfill near the smelter in Zvecan about 6.47 million t / pyrite, 3.31 million t / Pirot and $566000 \mathrm{t} / \mathrm{oligo}$.

\section{Heavy metal pollution from road traffic}

The main processes through which vehicles emit pollutants into the environment are combustion processes of fuel, vehicle depreciation (engine, tires, and brakes), and oil leakage or anti-freeze, and also corrosion (Lajçi \& Kalaj, 1998). While emission control regulations have led to a substantial reduction in emissions coming from road traffic, it has recently been noticed that emissions from other vehicles were not affected (Damek-Poprawa \& Sawicka-Kapusta, 2003). Accordingly, lead is released during fuel combustion processes, zinc dust is derived from tires (zinc catalyst used in the manufacture of tires), and copper is derived from the corrosion of the radiator and brakes; other heavy metals are 
from mixed backgrounds (Ferguson, 1989). Then origin of $\mathrm{Zn}$ of road traffic is from corrosion of ABS braking system (Dakonta, 2009). Today, most important heavy metals related to road traffic are: $\mathrm{Cu}$, $\mathrm{Pb}$, and $\mathrm{Zn}$. Historically, lead has been related to road traffic. Other metals coming from road traffic include, $\mathrm{Cd}, \mathrm{Cr}, \mathrm{Cu}, \mathrm{Ni}, \mathrm{Sb}$ and $\mathrm{Zn}$ from amortization of brakes, $\mathrm{Zn}$ and traces of $\mathrm{Cd}, \mathrm{Co}, \mathrm{Cr}, \mathrm{Cu}, \mathrm{Hg}$, $\mathrm{Mn}, \mathrm{Mo}, \mathrm{Ni}$ and $\mathrm{Pb}$ from tires and $\mathrm{Cd}, \mathrm{Cr}, \mathrm{Cu}, \mathrm{Ni}$, lead and $\mathrm{V}$, from gases released by burning fossil fuels (Qullaj, 2010).

The effects of pollution on health are of particular concern for the population of Kosovo. These effects are often significant and lead to major public debates. Therefore, the effects of pollution vary depending on the pollutants and include:

- Acute respiratory diseases;

- Worsening of patients condition who suffers from heart diseases, respiratory diseases, and asthma;

- Cancer caused directly by pollutants;

- Impacts on the eye or nose irritation and stress or loss of general welfare.

While in most cases, the effects are small, in some cases, the impact may be bigger and in extreme cases, the consequences are life-threatening. In 2016, 1045 people have been diagnosed with cancer, and half of them died. The government of Kosovo is paying 5 million for the chemotherapy chemicals treatment of persons diagnosed with CA.

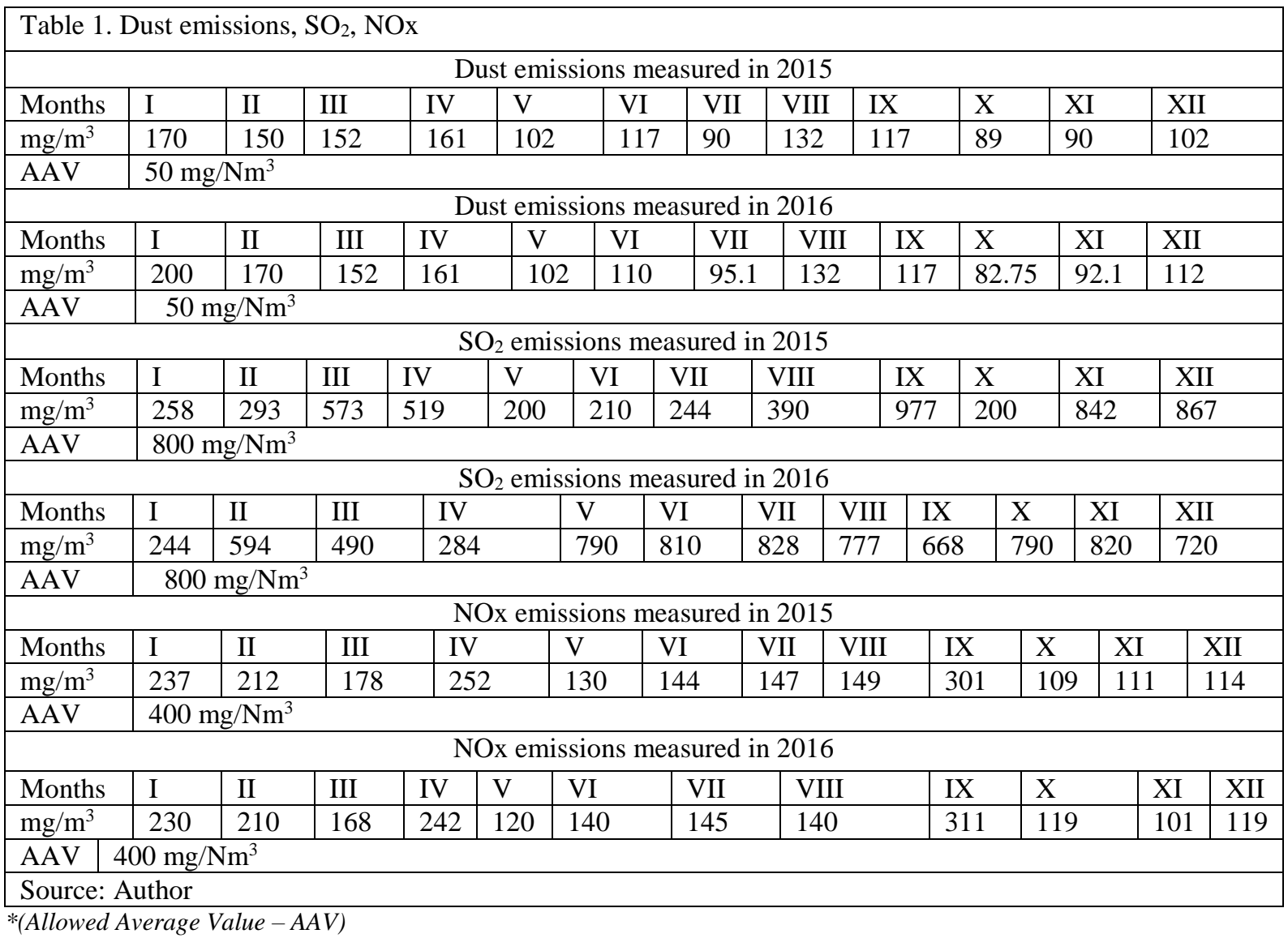

\section{Short and long term exposure to PM particles}

According to (Dreshaj, 2014) exposure to PM particles always refers to a respiratory disease, cardiovascular disease, and other consequences. PM10 particles are smaller than 10 micrometers in diameter, so they easily infiltrate into the respiratory tract (Law No. 04/L-197 on chemicals, 2014). It was found that an exposure to very small fractions of particles PM2,5, which account for about twothirds of PM10 emissions, results in an even stronger association of the observed effects on disease, but also warn that there are fractions between PM10 and PM2,5 which may have some influence on health (Qullaj, 2010). 


\section{Research Methodology and Materials}

The samples for the research have been taken at various stations in the center of Pristina, and in Kosovo Polje near the roadway.

After transporting the samples to the laboratory, the instruments used to measure the analysis were: Turnkey's - equipment for the measurement of particles. The photometry used in the Turnkey' instruments as Tapas, Osiris and the Dust mate provides a continuous and simultaneous overview of mass fractions PM 2.5, PM 10 and GPM (Dreshaj, 2013).

The dust mate portable monitor is a monitor laser detector and is ideal for sampling in the field. This device analyses the total particulate matter (TPM), the particulate matter with a diameter of $10 \mu \mathrm{m}$ (PM10), subject particles $2.5 \mu \mathrm{m}$ in diameter (PM 2.5), and the PM10 in a simultaneous way (Dreshaj, 2014). The monitor is equipped with software which is used for reading, receiving, management and interpretation of the data based on the relevant assessment criteria.

These results have been shown in Table 1.

The dynamics of the particles in the air-air measurements for indicators in Pristina are focused on two important stations representative to assess the impact of pollution sources in this city (Dreshaj, 2013).

\begin{tabular}{|l|l|l|l|l|l|l|}
\hline Table 2. Particulate matter with an aerodynamic diameter $<10 \mu \mathrm{m}(\mathrm{PM} 10)$ \\
\hline \multirow{7}{*}{ Stations } & \multicolumn{7}{|c|}{ Concentration $\mu \mathrm{g} / \mathrm{m}^{3}$} \\
\cline { 2 - 7 } & \multicolumn{7}{|c|}{2015} & \multicolumn{3}{c|}{2016} \\
\cline { 2 - 7 } & January & June & October & January & June & October \\
\hline PM10 Prishtina Center & 75.74 & 76.99 & 77.12 & 64.98 & 61.12 & 78.99 \\
\hline PM10 Kosovo Polje & 48.75 & 67.67 & 79.12 & 57.83 & 59.34 & 61.10 \\
\hline Source: Author &
\end{tabular}

\begin{tabular}{|c|c|c|c|c|}
\hline \multicolumn{3}{|c|}{ Average values of PM10 in 2016} & \multicolumn{2}{|c|}{$\frac{\text { Average monthly values of PM } 2.5 \text { in } 2016}{\text { Concentration PM10 }\left(\mu \mathrm{g} / \mathrm{m}^{3}\right)}$} \\
\hline $\begin{array}{l}\text { Concentrating } \\
\text { on site- } \\
\text { sampling }\end{array}$ & Concentra & PM10 $\left(\mu \mathrm{g} / \mathrm{m}^{3}\right)$ & Conce & $110\left(\mu \mathrm{g} / \mathrm{m}^{3}\right)$ \\
\hline Months & Kosovo Polje & Centre Pristina & Kosovo Polje & Centre Pristina \\
\hline January & 73 & 71 & 34 & 45 \\
\hline February & 64 & 59 & 39 & 39 \\
\hline March & 47 & 70 & 28 & 29 \\
\hline April & 65 & 79 & 35 & 51 \\
\hline May & 55 & 48 & 30 & 32 \\
\hline June & 71 & 100 & 49 & 60 \\
\hline July & 45 & 73 & 51 & 51 \\
\hline August & 72 & 69 & 49 & 39 \\
\hline September & 63 & 67 & 35 & 38 \\
\hline October & 51 & 90 & 56 & 51 \\
\hline November & 112 & 93 & 80 & 61 \\
\hline December & 114 & 82 & 91 & 67 \\
\hline Average & 69.333 & 75.08 & 48.083 & 46.91 \\
\hline
\end{tabular}

\section{Conclusions}

The main goal of this research has been to provide the necessary information in order to make correct decisions regarding the management and improvement of air quality. Based on the findings presented above, it can be concluded that the three polluting sources are characterized by differentiated emissions of air pollutants with particulate matters: PM10, PM 2.5, as well as $\mathrm{SO}_{2}, \mathrm{NOx}$, and CO.

The power plants/stations, Kosovo A and Kosovo B are powerful emitters into the air as well as of particulate material emissions. Emission of particulates on the annual average is about 9-16 times higher than AAV, while NOx emissions are 34-62\% higher than AAV. Pristina is characterized by a high load of particulate material. As for PM10 particulates and PM2.5 particulates, their annual average is $50-60 \%$ higher than the critical limits. 
Despite the fact that the Kosovo authorities have passed laws protecting air, water, forest and other environmental related areas, the management and improvement of air quality remain a serious concern for the life of people. Thus, the fundamental right of Kosovo citizens such as the right to healthy life continues to be at risk.

\section{Recommendations}

As a starting point, citizens should be aware that environmental protection protects health and wellbeing. In this regard, it should be initiated as soon as possible, since tomorrow it might be late. In order to improve the conditions, we recommend providing of funds for the maintenance of monitoring equipment. Also, based on the findings, we recommend increasing the number of monitoring parameters as required by the guidelines laid down by laws which regulate issues of air pollution. Moreover, to take concrete steps on the part of institutions in reducing pollution from PK 10 and PM 2.5. As regulated by legislation, to conduct control of fuels derivatives that enter Kosovo and become certified companies which deal with this business, to carry out technical inspection of vehicles and issuing gases and to adopt standards set by the European legislation level, discard vehicles that do not meet requirements, establishment of electrostatic filters in the chimneys of power plants/stations, and increase green areas inside and outside the cities.

Finally, Kosovo authorities might concentrate and orient their actions on controlling the enforcement of already passed legislation that regulates all the above mentioned aspects.

\section{Bibliography}

Dakonta. (2009). Consulting services for Environmental Assessment and Remedial Action Plan for Mitrovica Industrial Park, Kosovo, UNDP.

Damek-Poprawa, M. \& Sawicka-Kapusta, K. (2003). Damage to the liver, kidney, and testis with reference to burden of heavy metals in yellow-necked mice from areas around steelworks and zinc smelters in poland. Toxicology, 186(1-2), 1-10.

Davis Jr, K. B. \& McEntire, M. E. (2006). Comparison of the cortisol and glucose stress response to acute confinement and resting insulin like growth factor-concentrations among white bass, striped bass and sunshine bass. Aquaculture America Book of Abstracts pg. 79.

Dreshaj, A. (2014). Product Quality Management and Environmental Impacts in Business, Pristina. Olymp; ISBN, 978-9951635-32-5.

Ferguson, HW. (1989). Systemic pathology of fish: a text and atlas of comparative tissue responses in diseases of teleosts. Iowa State University Press, Ames, IA, 263p.

Dreshaj, A. (2013). Doctorate: Study chemical - environmental watershed White Drin and Ibar in Kosovo. University Tirana www.fshn.edu.al.

Daci, N. (1978). Organic Chemistry, University Natural Sciences Pristina: 04nr.413-235/80.

Lajçi, A. \& Kalaj, V. (1998). Chemistry, University of Pristina, Faculty of Natural Sciences. Nr .177/28 (1997).

Qullaj, A. (2010). Environmental Chemistry, University of Tirana, Faculty of Natural Sciences, ISBN: 978-99927-0-562-9.

Shehu, E. (2006). Basics of Chemical and Environmental Technology, Tirana University of Tirana, Faculty of Natural Sciences: ISBN 99927-931-3-9.

Veseli, B. (2015). Environmental impact of emission of harmful substances in air quality in Republic of Kosovo. PhD studies,

Law No. 04/L-197 on chemicals, 03 October 2014.

Law Nr. 04/ L-147 on Water, 29 April 2013.

Law No. 04/L-06 on waste, 24 September 2012.

Law No. 03/1-233 on nature protection, 28 May 2013.

Law No. 03/L-160 on air protection from pollution, 25 February 2010. 